\title{
Facial injuries in children and adolescents victims of aggression
}

\author{
Lesões faciais em crianças e adolescentes vítimas de agressão \\ Lesiones faciales en niños y adolescentes víctimas de agresiones
}

\begin{abstract}
Child maltreatment may occur as the intentional use of power, effective or attempted, against children under 18 years old, that results or may result in actual or potential harm. It affects a vulnerable population, causing physical and/or emotional consequences persisting throughout their lives. This study aimed to characterize episodes of child maltreatment, with focus on facial injuries, in a Brazilian city (Teresina, PI). This is a retrospective study with a quantitative approach, carried out in the database at the Institute of Forensic Medicine in Teresina, between the years 2017 and 2019. All reports of bodily injury of children from 0 to 18 years were collected and statistically analyzed (SPSS 22.0). During the period analysis, 811 reports of bodily injury were identified. There was a predominance of female victims aged between 12 and 18 years old, the involvement of men with some family relationship with the victim was highly associated. Facial injuries represented $35.8 \%$ of the whole sample and $98.6 \%$ of those found in the head and neck region (41,6\% of the total). The orbital (29.0\%) was the most affected site, followed by the frontal (25.9\%), malar (23.4\%), labial (17.6\%) and cheek area (11.4\%). There is a high prevalence of injuries to the head and neck region, this fact emphasizes the importance of a trained professional, especially a dental surgeon, in the analysis and interpretation of these injuries during forensic examination.
\end{abstract}

Keywords: Child abuse; Aggression; Facial injuries; Child; Adolescent; Forensic dentistry.

\section{Resumo}

Maus-tratos infantis podem ocorrer como uso intencional da força, efetiva ou na forma tentada, contra crianças menores de 18 anos, que resulta ou pode resultar em dano real ou potencial. Afeta uma população vulnerável, causando consequências físicas e / ou emocionais que persistem por toda a vida. Este estudo teve como objetivo caracterizar episódios de maus-tratos infantis, com enfoque nas lesões faciais, em uma cidade brasileira (Teresina, PI). Trata-se de um estudo retrospectivo com abordagem quantitativa, realizado no banco de dados do Instituto Médico Legal de Teresina, entre os anos de 2017 e 2019. Todos os laudos de lesões corporais de crianças de 0 a 18 anos foram coletados e analisados estatisticamente (SPSS 22,0). No período de análise, foram identificados 811 relatos de lesões corporais. Houve predomínio de vítimas do sexo feminino na faixa etária de 12 a 18 anos, o envolvimento de homens com alguma relação familiar com a vítima foi altamente associado. As lesões faciais representaram 35,8\% do total da amostra e $98,6 \%$ das encontradas na região de cabeça e pescoço (41,6\% do total). A região orbital $(29,0 \%)$ foi a mais acometida, seguida pelo frontal $(25,9 \%)$, malar $(23,4 \%)$, labial $(17,6 \%)$ e bochecha $(11,4 \%)$. A prevalência de lesões na região de cabeça e pescoço é elevada, fato que enfatiza a importância de um profissional capacitado, principalmente o cirurgiãodentista, na análise e interpretação dessas lesões durante o exame pericial.

Palavras-chave: Maus-tratos infantis; Agressão; Traumatismos faciais; Criança; Adolescente; Odontologia legal. 


\begin{abstract}
Resumen
El maltrato infantil puede ocurrir como el uso intencional de poder, efectivo o intentado, contra niños menores de 18 años, que resulte o pueda resultar en un daño real o potencial. Afecta a una población vulnerable, provocando consecuencias físicas y / o emocionales que persisten a lo largo de su vida. Este estudio tuvo como objetivo caracterizar episodios de maltrato infantil, con foco en lesiones faciales, en una ciudad brasileña (Teresina, PI). Se trata de un estudio retrospectivo con abordaje cuantitativo, realizado en la base de datos del Instituto de Medicina Forense de Teresina, entre los años 2017 y 2019. Todos los reportes de lesiones corporales de niños de 0 a 18 años fueron recolectados y analizados estadísticamente (SPSS 22,0). Durante el análisis del período, se identificaron 811 informes de lesiones corporales. Hubo un predominio de mujeres víctimas con edades comprendidas entre los 12 y 18 años, la participación de los hombres con alguna relación familiar con la víctima estuvo altamente asociada. Las lesiones faciales representaron el 35,8\% del total de la muestra y el 98,6\% de las encontradas en la región de cabeza y cuello (41,6\% del total). El orbitario $(29,0 \%)$ fue el sitio más afectado, seguido del frontal $(25,9 \%)$, malar $(23,4 \%)$, labial $(17,6 \%$ y mejilla $(11,4 \%)$. Existe una alta prevalencia de lesiones en la región de la cabeza y el cuello, este hecho enfatiza la importancia de un profesional capacitado, especialmente un cirujano dentista, en el análisis e interpretación de estas lesiones durante el examen forense.
\end{abstract}

Palabras clave: Maltrato a los niños; Agresión; Traumatismos faciales; Niño; Adolescente; Odontología forense.

\title{
1. Introduction
}

Child maltreatment is considered a social and public health problem that indiscriminately affects all countries. "It includes all types of physical and/or emotional ill-treatment, sexual abuse, neglect, negligence and commercial or other exploitation, which results in actual or potential harm to the child's health, survival, development or dignity in the context of a relationship of responsibility, trust or power" (World Health Organization [WHO], 2014). In this context, physical violence is defined as the intentional use of power, effective or attempted, that results, or may result, in actual or potential harm (Pinheiro, 2006). Children are more vulnerable to this type of violence as they are still in the process of autonomy development (Salgado et al., 2016).

Several studies have indicated that physical violence is the most commonly type of violence against children observed worldwide. In Brazil, it is estimated that 18 thousand children are victims of physical aggression daily; $35 \%$ of them suffer recurrent episodes (Barreto, Araujo, Matins Júnior, Barreto Filho \& Costa, 2018).

In a study carried out in Tanzania on the types of violence suffered in childhood, the prevalence of physical abuse was 82.1\% (Mwakanyamale, Wande \& Yizhen, 2018).

When it comes to violence against children, relevant issues are raised regarding the physical, psychological and social consequences in the short and long term. Some of these consequences are manifested through undesirable behaviors, including use of drugs, prostitution, involvement in abusive relationships, self-harm, and suicidal intentions (O’brien, White, Wu, \& KillinFarrel, 2016). The intervention requires an interdisciplinary and multidisciplinary approach, including direct health practitioners, social, legal, psychological, anthropological, religious support. During professional training, the topic "child maltreatment" must be always discussed beside prevention and citizenship promotion (Apostólico, Nóbrega, Guedes, Fonseca \& Eggry, 2012).

In Brazil, when an episode of violence against children occurs, the victim is referred to the Institute or Department of Forensic Medicine for examination of bodily injury. This referral is carried out by the police officer or judicial authority, it can be requested to one of them directly by the Public Ministry (Lei n. 3.689, 1941). The forensic report is attached to the criminal process to be tried under the criminal law (Lei n. 3.689, 1941).

Studies on bodily injury associated to child maltreatment addressing the prevalence of facial injuries are scarce in the literature. This type of study is relevant to increase the issue visibility and promote effective public policy strategies to support the criminal process and the application of the criminal law, as well as emphasize the importance of a trained professional, especially a dental surgeon, at the Institute of Forensic Medicine. This study aimed to characterize episodes of child aggression, with focus on facial injuries, in a Brazilian city (Teresina, PI). 


\section{Methods}

This is a retrospective study with a quantitative approach, carried out in the database at the Institute of Forensic Medicine, located in the city of Teresina-PI, which is responsible for conducting forensic exams in Teresina and 61 other cities in the state of Piauí.

The study was carried out through the collection of secondary data present in forensic reports stored in the database of the mentioned institution. Inclusion criteria were considered: all reports of bodily injury carried out from January 2017 to December 2019; whose victims were children from 0 to 18 years old. Reports resulting from reasons other than physical violence were excluded of the study; just as reports not concluded by the professional in charge or even canceled due to administrative mistakes.

Variables related to the victim's sociodemographic data (age and sex) and data from the violence episode (sex of the aggressor; involvement with the victim; location where the violence occurred; presence of injury; anatomical region of the body where the injury occurred, type of injury; instrument used to produce the injury) were collected. Only one investigator collected the data, thus ensuring a standardized record of all information presented.

Data was double checked using Microsoft Excel application and later exported and analyzed using the SPSS software, version 22.0. In order to characterize the sample, descriptive statistics of absolute and relative frequency were performed. Fisher's exact test was used to verify the association between qualitative variables, with a significance level of $5 \%$. The Institutional Ethical Committee approved the study protocol (Process number 4.100.295).

\section{Results}

Between 2017 and 2019, 2,077 reports of violence against children were identified. Among these, 811 (39.0\%) reports indicated physical violence. In this period, there has been a decrease in the number of reports over time, 379 in 2017,221 in 2018, and 211 in 2019. Table 1 shows the distribution of reports according to sociodemographic and violence-related variables. There was a predominance of female victims aged between 12 and 18 years old, the involvement of men with some family relationship with the victim is highly associated. The violence occurred most frequently at home, there was identification of bodily injury in most part of the reports, and the examination was performed within 24 hours of the occurrence of the violence. 
Table 1. Distribution of physical violence reports against children according to sociodemographic and violence-related variables. Teresina, $2020(\mathrm{n}=811)$.

\begin{tabular}{lcc}
\hline \multicolumn{1}{c}{ Sociodemographic and violence-related variables } & $\mathrm{N}$ & $\%$ \\
\hline Sex & & \\
Male & 354 & 43,6 \\
Female & 457 & 56,4 \\
Age & & \\
0-11 years & 237 & 29,2 \\
12-18 & 574 & 70,8 \\
Sex of the suspect & & \\
$\quad$ Male & 393 & 48,5 \\
Female & 207 & 25,5 \\
Not informed & 211 & 26,0 \\
Relationship with the suspect & & \\
Intra-familial- parent & 134 & 16,5 \\
Intra-familial- other & 158 & 19,5 \\
Extra-familial & 309 & 38,1 \\
Other & 1 & 0,1 \\
$\quad$ Not informed & 209 & 25,8 \\
\hline Violence Location & & \\
$\quad$ Home & 223 & 27,5 \\
School & 62 & 7,6 \\
Public area & 128 & 15,8 \\
Other & 54 & 6,7 \\
Not informed & 344 & 42,4 \\
Presence of bodily injury & & \\
Yes & 706 & 87,1 \\
No & 105 & 12,9 \\
Time interval between injury and examination & & \\
$\quad$ Until 24 hours & 437 & 53,9 \\
24-72 hours & 88 & 10,9 \\
3-7 days & 102 & 12,6 \\
8-15 days & 18 & 2,2 \\
More than 15 days & 41 & 5,1 \\
$\quad$ Not informed & 125 & 15,4 \\
\hline Total & 811 & 100,0 \\
\hline
\end{tabular}

Source: Forensic reports from IML Teresina, PI.

There was a predominance of lesions located in the head and neck region (41.6\%), followed by the upper limbs (38.2\%) (Figure 1). 
Figure 1. Distribution of violence reports against children according to the affected body region. Teresina, 2020. $(\mathrm{n}=706)$

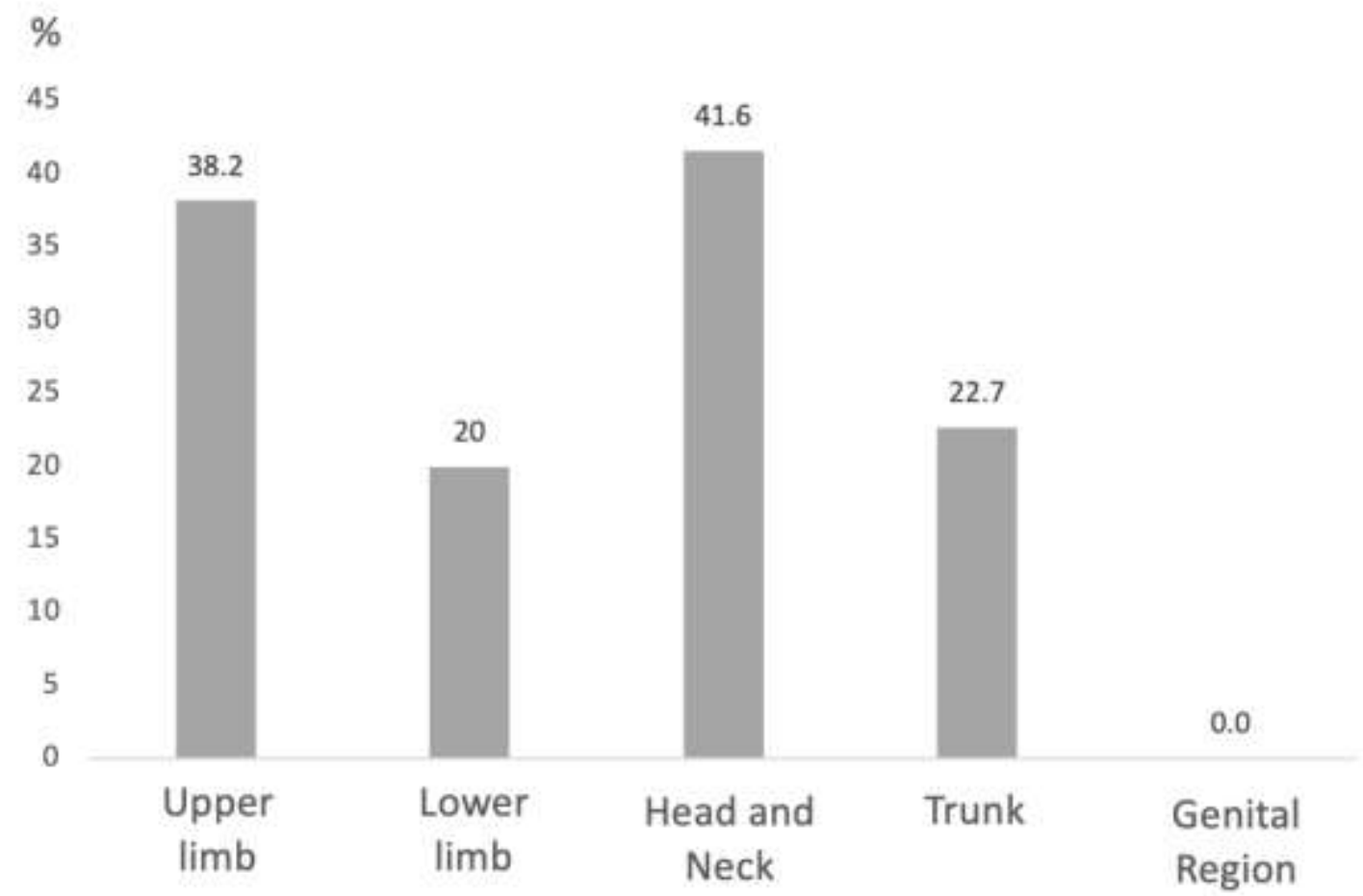

Source: Forensic reports from IML Teresina, PI.

Among the bodily injuries, those located in the facial region are noteworthy, they represented $35.8 \%$ of the whole sample and $98.6 \%$ of those found in the head and neck region. Table 2 shows the distribution of the facial injuries identified in the forensic reports of physical violence against children. The orbital region was the most affected site, followed by the frontal, malar, labial and cheek areas.

Table 2. Distribution of facial injuries identified in the forensic reports of physical violence against children in the period 2017 2019. Teresina, $2020(n=290)$.

\begin{tabular}{|c|c|c|}
\hline Facial Region* & $\mathrm{N}$ & $\%$ \\
\hline Orbital & 84 & 29,0 \\
\hline Frontal & 75 & 25,9 \\
\hline Malar & 68 & 23,4 \\
\hline Labial & 51 & 17,6 \\
\hline Nasal & 27 & 9,3 \\
\hline Zygomatic & 17 & 5,9 \\
\hline Masseter & 14 & 4,8 \\
\hline Hemiface & 20 & 6,9 \\
\hline Mentonian & 14 & 4,8 \\
\hline Dental injuries & 4 & 1,4 \\
\hline Oral mucosa & 8 & 2,7 \\
\hline Cheek & 33 & 11,4 \\
\hline
\end{tabular}

* Multiple choice variable. Source: forensic reports from IML Teresina, PI. 
Among the forensic reports with identification of facial lesions, the most prevalent lesions were ecchymosis (31.8\%), swelling (29.6\%) and excoriation (22.2\%) (Figure2). Blunt instruments were the most type of instrument recorded (Figure 3).

Figure 2. Distribution of violence reports against children identified with lesions in the facial region according to the classification of injuries. Teresina, 2020. $(n=290)$.

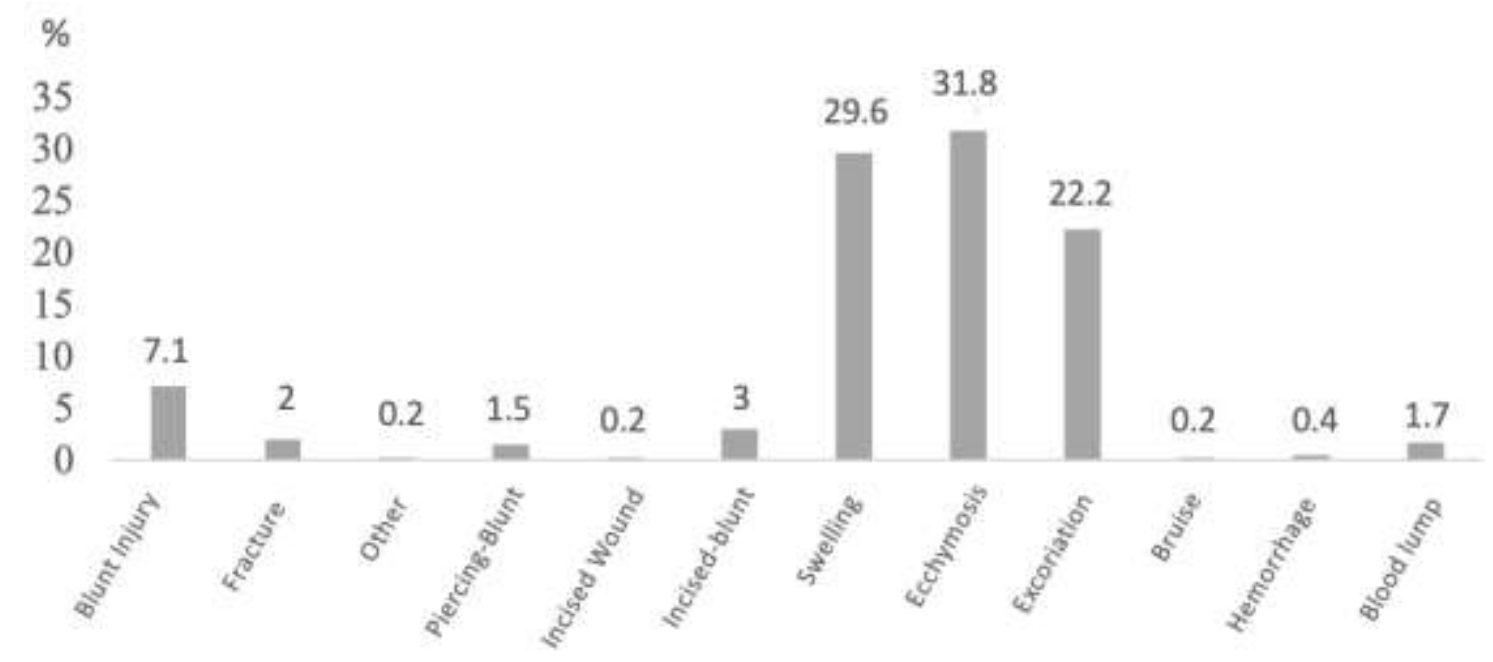

Source: Forensic reports from IML Teresina, PI.

Figure 3. Distribution of violence reports against children identified with lesions in the facial region according to the type of instrument used. Teresina, 2020. $(\mathrm{n}=290)$.

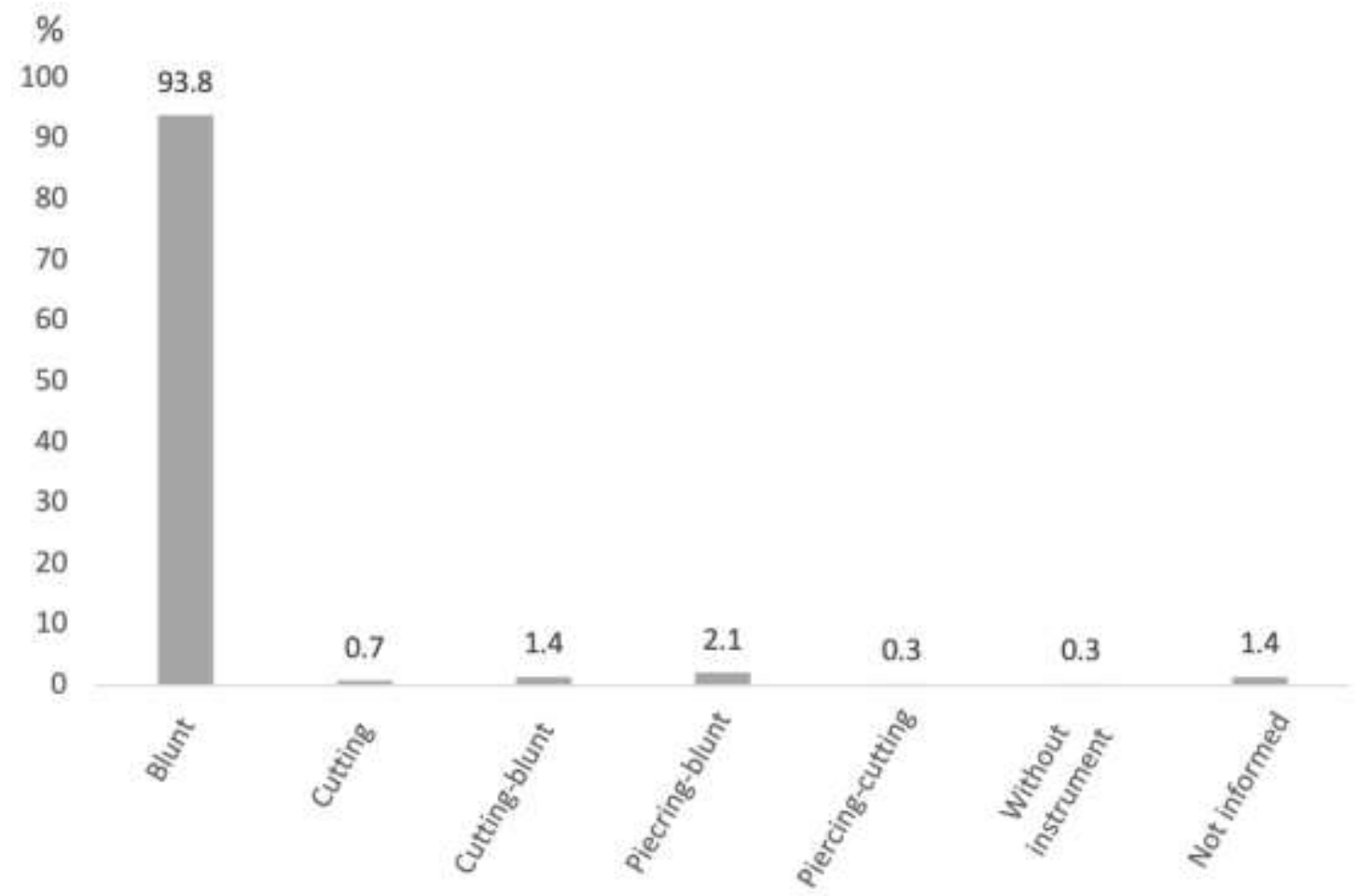

Source: Forensic reports from IML Teresina, PI. 
When analyzing the association of sex and age with variables related to injuries (Table 3), there is a significant difference between age and the presence of personal injury $(\mathrm{p}=0.023)$, with a higher percentage of personal injury in the age group 12-18 years (teenagers) ; between age range and location of the lesion $(\mathrm{p}=0.0001)$ with predominance of lesions in the trunk and lower limbs in children and in the head and neck and upper limbs in teenagers; and between sex and location of the lesion ( $\mathrm{p}=0.022)$, with a predominance of lesions in the trunks and genital region for males comparing to females.

Table 3. Association between variables related to injuries and sex and age group of victims of violence. Teresina, 2020.

\begin{tabular}{|c|c|c|c|c|c|c|}
\hline \multirow[t]{4}{*}{ Variables related to injuries } & \multicolumn{2}{|c|}{ Sex } & $P^{*}$ & \multicolumn{2}{|c|}{ Age group } & \multirow[t]{3}{*}{$P^{*}$} \\
\hline & Male & Female & & $0-11$ years & $12-18$ & \\
\hline & & & & & years & \\
\hline & $\mathrm{N}(\%)$ & $\mathrm{N}(\%)$ & & $\mathrm{N}(\%)$ & $\mathrm{N}(\%)$ & \\
\hline Presence of bodily injury & & & 0,391 & & & $\mathbf{0 , 0 2 3}$ \\
\hline Yes & $310(87,6)$ & $396(86,6)$ & & $197(83,1)$ & $509(88,7)$ & \\
\hline No & $44(12,4)$ & $61(13,4)$ & & $40(16,9)$ & $65(11,3)$ & \\
\hline Injury location & & & 0,022 & & & $\mathbf{0 , 0 0 0}$ \\
\hline Upper limb & $118(25,9)$ & $192(32,7)$ & & $62(22,8)$ & $248(31,8)$ & \\
\hline Lower limb & $65(14,3)$ & $97(16,5)$ & & $46(16,9)$ & $116(14,9)$ & \\
\hline Head and neck & $155(34,1)$ & $211(36,0)$ & & $91(33,5)$ & $275(35,3)$ & \\
\hline Trunk & $114(25,1)$ & $87(14,8)$ & & $71(26,1)$ & $140(17,9)$ & \\
\hline Multiple injuries & $1(0,2)$ & $-(0,0)$ & & $-(0,0)$ & $1(0,1)$ & \\
\hline Genital region & $2(0,4)$ & $-(0,0)$ & & $2(0,7)$ & - & \\
\hline
\end{tabular}

*Fisher's exact test, with a significance level of 0.05 . Source: forensic reports from IML Teresina, PI.

\section{Discussion}

The results of this study show that violence against children and teenagers at the Institute of Forensic Medicine in Teresina is a usual event, and most of the injuries affect the head and neck region, frequently in the facial area.

The reduction in the number of occurrences observed in the 3-year period of the investigation may be due to preventive policies promoted by government and non-government institutions that create protection networks to face the violence against children. Credits should also be given to the improvements in the cultural pattern of education against the violence and social awareness (Ministério da Saúde [MS], 2006).

The analysis of gender distribution showed a higher prevalence of physical ill-treatment in females, this data contrasts with studies that indicate that male children are more affected by physical violence (Cavalcanti, 2010; Cavalcanti \& Martins, 2009; Vidal et al., 2018; Vidal et al., 2019; O’brien et al., 2016; Rodrigues Júnior, 2009; Leite Filho, 2017). Only one study, carried out using data from the Disease Information and Notification System (SINAN in Brazil), in the state of Piauí, between 2007 and 2016, found a higher percentage of female child maltreatment victims (51.7\%) (Almeida, dos Anjos \& Sousa, 2017). Likewise, a study carried out at the same Legal Medical Institute between the years 2018 and 2020, found that the sex most victimized by sexual violence among children and adolescents was the female. This data reinforces the evidence of female fragility in gender relations, whether due to the condition of superior physical strength of the male gender, the inequality expressed in gender relations and the vulnerability and risk of women for victimization by violence, especially for children and adolescents (Trajano, Lyra, e Sá \& Gomes, 2021). 
Considering the age group, there was an increase in the number of victims as the age progress, with a higher percentage of bodily injury among teenagers (>12 years), corroborating the findings of other studies (Cavalcanti, 2010; Vidal et al., 2019; O'brien et al., 2016; Almeida et al., 2017; Silva, Musse, Almeida, Marques \& Costa, 2016). This can be explained by the fact that young people experience greater social exposure than children under 12 years, as well as the increased capacity and autonomy to make denunciations when older children are involved .

The profile of the suspects, for the most part, was not associated with family members, just as found in other studies where suspects were involved with victims' relatives, but they were not considered family (Cavalcanti \& Martins, 2009; Vidal et al., 2019; Almeida et al., 2017; Silva et al., 2016). However, studies carried out in Haiti (O'brien et al, 2016) and Brazil (Rio de Janeiro) (Silva, Costa, Musse, Almeida \& Vilas Boas, 2018) found that the aggression was more frequently committed by family members.

A quarter of the forensic reports evaluated did no have information about the victim's relationship with the suspect (25.8\%) and the sex (26\%) of the suspect. Information about the alleged perpetrator could assist the judicial authority in the process conduction including which law properly fit the fact. Unfortunately, there is no standard to collect this data, the professional responsible for collecting this data must be clearly defined and trained, the forensic examiner must double check this information.

When observing the time interval between the occurrence of the event and the performance of the forensic examination, most of the examinations occurred in the first 24 hours, which may explain the presence of injury in $87.1 \%$ of the cases, while some physical evidence might not last longer. In a similar study carried out in Portugal (Vidal et al., 2018), a longer time (2 days) between the aggression and the examination was observed. It is worth mentioning that in $15.4 \%$ of the exams there was no information about the time interval (between event and examination), allowing inconsistencies between the moment when the violence occurred and the evolutionary phase of the bodily injury (França, 2015).

Although the presence of injuries has not been observed during the forensic examination of some cases (12.9\%), the occurrence of the violence is not excluded. The time between the event and examination may be too long or the intensity of the aggression was not enough to leave some evidence behing in the body of the victim. Blood congestions provoke some skin redness that may disappear in a few minutes (França, 2015).

Regarding the distribution of injuries in the victims' body, the head and neck are the most affected areas, followed by upper limbs. Studies have shown that $29 \%$ to $56.3 \%$ of cases of child maltreatment some trauma was present to the mouth, face and head (Cavalcanti, 2010; Vidal et al, 2018; Vidal et al., 2019; Rodrigues Júnior, 2009; Silva et al., 2018). The higher frequency of injuries in the head and neck areas is due to the fact that they are more exposed and accessible areas since the suspect is usually taller than the victim. While the injuries on the arms are associated with victims' attempts of defense (Vidal et al., 2018).

The face is usually affected due to the process of subjugation and humiliation inherent in the aggression act, due to its vulnerability and psychological impact (Cavalcanti, 2010). Other retrospective study carried out in Brazil (Campina Grande PB), with similar methodology, pointed out a high prevalence of injuries to the facial region of physically abused children, with soft tissue lacerations being commonly found, mainly in the upper lip (Cavalcanti, 2010).

In this study, the orbital, frontal, malar, labial and cheek regions were the most affected, respectively. Other study carried out in Brazil (Recife-PE), found the face as the most affected site (20.1\%) in cases of child maltreatment, with the eyes, mouth and nose the organs most likely to be affected (Vidal et al., 2018). Other investigation carried out in a children's hospital in South Africa (Naidoo, 2000), which analyzed injuries located on the head and neck, found that $59 \%$ of the total were facial and $11 \%$ intraoral. Taking a look only at facial injuries, $30 \%$ were located in the cheek, $25 \%$ in the orbital and $22 \%$ in the frontal region (Naidoo, 2000). Other investigation on the topic mentioned the numbers of $85.7 \%$ for facial and $25.7 \%$ intra-oral injuries (Banheiro, Escobar \& Pereira, 2015). 
Dental injuries in cases of child abuse usually include fractures, tooth luxation, subluxation and avulsions. In the present study, these types represented only $1.4 \%$ of all injuries in the face region, that is in contrast with the literature where intraoral injuries constitute a significant number over the sample, representing $30.8 \%$ of lesions on the face (Vidal et al., 2018).

Ecchymosis, swelling and excoriation were highly prevalent in the present study, differing from other study that points to cut-blunt (bruise trauma with some penetration in the tissue) injuries (Cavalcanti, 2010). According to the data in our study, the instrument most used in the production of facial injuries were blunt instruments. Other research performed in Brazil (Feira de Santana - BA) (Leite Filho, 2017), evaluated bodily injuries in children victims of physical violence, found the blunt instrument as the most prevalent (83.5\% ), but sharping and piercing instruments were associated to injuries to the head and neck region (84.9\%). . In another study in Belo Horizonte, also in Brazil, the "blunt" instrument was present in 91.9\% of the cases of violence against children (Rodrigues Júnior, 2009).

As a limitation of this study, the retrospective assessment through forensic reports performed by different experts, in a poorly standardized way, is highlighted. However, despite this limitation, the results described the high prevalence of facial injuries resulting from physical violence against children. It is noteworthy that orofacial injuries are strongly associated with case of child maltreatment, the dental surgeon, especially those with expertise in forensic dentistry, is technically the most qualified professional to analyze and interpret such injuries during the forensic examination.

\section{Final Considerations}

The study shows a significant prevalence of physical violence against children and adolescents. There is a predominance of females, aged 12 to 18 years, male aggressor, the home was the most pointed place for the occurrence of violence.

Regarding the affected body region, there was a predominance of lesions located on the head and neck and, among these, those located in the bucofacial region. This fact emphasizes the importance of a trained professional, especially a dental surgeon, in the analysis and interpretation of these injuries during forensic examination.

\section{References}

World Health Organization (WHO). (2014). Global status report on violence prevention. Geneva: World Health Organization.

Pinheiro, P. S. (2006). World report on violence against children. United Nations Secretary-General's study on violence against children. Geneva, ATAR Roto Presse AS.

Salgado, G. P., Costa, G. A., Rocha, C. M., Rocha, W. M. S., Carvalho, A. S. C., \& Pinheiro, I. C. (2016). Importância do pediatra na identificação de aspetos orofaciais sugestivos de maus-tratos infantis. Rev Med Minas Gerais, 26(5), 140-144.

Barreto, C. S. L. A., Araujo, R. P. C., Martins Junior, D. F., Barreto Filho, R. C., \& Costa, M. C. O. (2018). Perfil da violência que vitima crianças no estado da Bahia, segundo registros do Sistema de Gerenciamento Estatístico (SGE) da Secretaria de Segurança. Rev. Saúde Col. UEFS, 8, 8-15.

Mwakanyamale, A. A., Wande, D. P., \& Yizhen Y. (2018). Multi-type Child Maltreatment: Prevalence and its Relationship with self-esteem among secondary school students in Tanzania. BMC Psychology, 6.

O’brien, J. E., White, K., Wu, Q., \& Killin-Farrel, C. (2016). Mental Health and Behavioral Outcomes of Sexual and Nonsexual Child Maltreatment Among Child Welfare-Involved Youth. Journal of child sexual abuse, 13(56). 10.1080/10538712.2016.1167801

Apostólico, M. R., Nobrega, C. R., Guedes, R. N., Fonseca, R. M. G. S., \& Egry, E. Y. (2012). Características da violência contra a criança em uma capital brasileira. Rev. Latino-Am. Enfermagem, 20(2).

Brasil.. Decreto lei n 3.689, de 03 de outubro de 1941. Código de Processo Penal.

Brasil. (2006). Violência faz mal à saúde. Ministério da Saúde.

Cavalcanti, A. L. (2010). Prevalence and characteristics of injuries to the head and orofacial region in physically abused children and adolescents - a retrospective study in a city of the Northeast of Brazil. Dent Traumatol, 26, 149-53. 10.1111/j.1600-9657.2009.00859.x

Cavalcanti, A. L., \& Martins, V. M. (2009). Perfil epidemiológico da criança e adolescente vítimas de violência física: estudo no departamento de Medicina Legal de Campina Grande/PB. Arquivos Catarinenses de Medicina, 38(4), 67-72. 
Research, Society and Development, v. 10, n. 4, e43710414105, 2021

(CC BY 4.0) | ISSN 2525-3409 | DOI: http://dx.doi.org/10.33448/rsd-v10i4.14105

Vidal, H. G., Caldas, I. M., Coelho Junior, L. G. T. M., Souza, E. H. A., Carvalho, M. V. D., Soriano, E. P., Pereira, M. L., \& Caldas Junior, A. F. (2018). Orofacial Injuries in Children and Adolescents (2009-2013): A 5-Year Study In Porto, Portugal. Braz. Dent J, 29(3), 316-320.

Vidal, H. G., Caldas, I. M., Caldas Junior, A. F., Coelho Junior, L. G. T. M., Souza, E. H. A., \& Pereira, M. L. (2019). Physical violence against children and adolescents in Recife: a 5-year retrospective study. J Forensic Odontosmatol, 37(1), 20-5.

O’brien, K. T. F., Rivara, F. P., Weiss, N. S., Lea, V. A., Marcellin, L. H., Vertefeuille, J., \& Mercy, J. A. (2016). Prevalence of physical violence against children in Haiti: A national population-based cross-sectional survey. Child Abuse Negl, 51, 154-162. 10.1016/j.chiabu.2015.10.021

Rodrigues Junior, J. B. R. (2009). Avaliação Crítica das Perícias de Lesões Corporais em Crianças no Instituto Médico-Legal de Belo Horizonte - Minas Gerais - durante o período de um ano e da Contribuição na Investigação do Crime de Maus-tratos. Dissertação de Mestrado, Universidade Federal de Minas Gerais, Belo Horizonte, MG, Brasil.

Leite Filho, H. (2017). Características das lesões corporais decorrentes de violência física em crianças e adolescentes registrado no instituto médico legal (iml) em feira de santana - bahia, no ano de 2014. Anais seminário de iniciação cientifica.

Almeida, L. A., dos Anjos, S. L. S., \& Sousa, K. A. A. (2017). Epidemiologia da violência infantil um estado do nordeste do Brasil: série histórica de 2007 a 2016. Rev Pre Infec e Saúde, 3(2), 27-33. 10.26694/repis.v3i2.6457

Trajano, R. K. N., Lyra, C. V. V., e Sá, T. Y. G., Gomes, A. C. A. (2021). Comparativo de casos de violência sexual contra crianças e adolescentes no período 2018-2020. Research, Society and Development, 10(1).

Silva. M. L. C. A., Musse, J. O., Almeida, A. H. V., Marques, J. A. M., Costa, M. C. O. (2016). Injúrias dentárias traumáticas em crianças e adolescentes vítimas de violência periciadas no Instituto Médico Legal de Feira de Santana, $R F O$, 21(1), 31-6.

Silva, M. L. C. A., Costa, M. C. O., Musse, J. O., Almeida, A. H. V., \& Vilas Boas, C. D. F. (2018). Lesões corporais em adolescentes vítimas de violência física: casos periciados no Instituto Médico Legal. Rev Adolesc. Saude, 15(1), 18-25.

França, G. V. (2015). Medicina Legal. (10a ed.). Guanabara Koogan.

Naidoo, S. (2000). A profile of the oro-facial injuries in child physical abuse at a children's hospital. Child Abuse Negl, 24(4), 521-34. 10.1016/s01452134(00)00114-9

Banheiro, R., Escobar, P., \& Pereira, C. P. (2015). Injuries of Non-Lethal Child Physical Abuse to the Crania and Orofacial Regions. A Scientific Review. $J$ Forensic Res, 6, 285. 10.4172/2157-7145.1000285 